\title{
Academic Outcomes in School-Age Children with Stunting and Non-Stunting
}

\author{
Wahyu Indah Dewi Aurora ${ }^{1}$ \\ ${ }^{I}$ Department IKM-KK Medical Faculty and Health Science, Universitas Jambi \\ Corresponding Author: Email: auroradr@unja.ac.id
}

\begin{abstract}
Stunting is defined as a chronic malnutrition condition for children. The prevalence of children under five suffering from stunting in Indonesia in 2018 is still high at 30\%, still very far from the standard set by WHO, which is $20 \%$. With this high enough figure, of course, it will have an impact on the future of the nation's children in the future, one of which is academic achievement. The method used, the study was conducted quantitatively with an observational analytic design with unmatching case-control. The population in this study were all students of SD Negeri in Palembang City. A sample of 150 consisting of 75 stunting cases and 75 controls with the sampling technique, namely the consecutive sampling technique. The analysis used was univariate and bivariate chi-square. The result is that children who are stunted and get less than average academic achievement are $51.72 \%$ and whose academic achievement is more than the average is $49.59 \%$, whereas children who are not stunted and get less than average academic achievement. the average is $48.28 \%$ and the academic achievement is more than the average is $50.41 \%$. From the bivariate analysis, it was obtained that the value of $\mathrm{p}=0.04$ and $\mathrm{OR}=1.08$ (95\% CI: 0.446-2.668). The conclusion is that there is a meaningful relationship between the academic achievement of school-age children and stunting status, and children with stunting status have a 1.08 times likelihood of achieving less than average academic achievement.
\end{abstract}

Keywords: Academic achievement, School-age children, Stunting.

\section{INTRODUCTION}

Stunting is defined as a chronic malnutrition condition so that when compared to children of his age, his body will look shorter [1]. Measurement of stunting assesses the nutritional status of children based on height per age with the category of stunting if the nutritional status results are less than -2.0 SD and normal if more or equal to $-2 \mathrm{SD}$ according to the WHO standard [2]. This stunting problem is the main subject experienced by the world with a fairly high morbidity rate of more than $28 \%$, where the prevalence of stunting in Asia is 38\% and even in parts of Africa with a rate of $40 \%$, then WHO sets the standard for this stunting problem is $20 \%$ [3]. The prevalence of children under five suffering from stunting in Indonesia in 2018 is still high at $30 \%$, still very far from the standards set by WHO [4].
With this high enough figure, it will certainly have an impact on the future of the nation's children in the future. One of the effects is intelligence, where the damage caused by malnutrition during the growth period will be persistent or irreparable so that the impact will be seen at a later age [1]. This child's health must be fulfilled by every child to grow and develop optimally. If it grows and develops in a good direction from birth to school age, of course, there will be a smart generation of future lives. Children's health includes physical, spiritual, and social health, not only related to disease but also with physical development, intellectual and emotional intelligence [5]. Previous studies have stated that children with stunting will affect cognitive development, and have difficulty keeping up with educational attainment in school [6] [7]. This article aims to look at and analyze the academic performance achieved in stunted children compared to normal children. 


\section{METHODS}

This type of research is a quantitative study, the design used is observational analytic with an unmatching casecontrol approach, which is comparing 2 groups (the case group and the control group) [8]. The research was conducted in August - October 2019 in Palembang City. The population in this study were all students of SD Negeri in Palembang City. A sample of 150 consisting of 75 stunting cases and 75 controls with the sampling technique, namely the consecutive sampling technique. The inclusion criteria were primary school children in three sub-districts of Palembang City (Sukarame, Seberang Ulu 1 and Seberang Ulu 2), aged 9-12 years for the case group suffering from stunting with TB / U (height-for-age) Zscore less than - 2SD, whereas for the control group with normal nutritional status.

The exclusion criteria were children with a history of congenital defects and growth disorders. Stunting variables were measured using a microtoise height measuring device, as well as using software to analyze the $\mathrm{z}$-score in determining categorical nutritional status. Assessment of academic achievement uses the average value of the last semester report cards. The data analysis used was univariate analysis for frequency distribution and also bivariate chi-square analysis to determine the relationship between academic achievement and stunting status.

\section{RESULT}

The results of this study are described in Table 1, which describes the frequency distribution of the respondents. Where from 150 respondents most of the respondents were 11 years old $42.68 \%$, male gender $46.75 \%$, academic achievement was above the average $79.33 \%$

Table 1. Distribution and Frequency Characteristics of Respondents

\begin{tabular}{|l|c|c|}
\hline \multirow{2}{*}{ Variable } & \multicolumn{2}{c|}{ Total } \\
\cline { 2 - 3 } & $\mathbf{N}$ & $(\%)$ \\
\hline Ages & & \\
$9-10$ Years & 74 & 49,3 \\
11 - 12 Years & 78 & 50,7 \\
\hline Gender & 70 & 46,75 \\
Male & 80 & 53,3 \\
Female & & \\
\hline Stunting Status & 75 & 50 \\
Stunting & 75 & 50 \\
Normal & 29 & 19,3 \\
\hline Academic Outcomes & & 80,67 \\
< Averages & 121 & \\
> Averages & & \\
\hline
\end{tabular}

Assessment of academic achievement is assessed from the final semester report card scores of respondents, with an average passing limit of 70 . Respondents with an average score above 70 are categorized as more than average, while respondents with an average score below 70 are categorized as less than average. - average. Respondents with categories more than the average were 121 (80.67\%) while respondents with categories less than the average were 29 respondents $(19.3 \%)$.

Table 2. Describes bivariate analysis between academic achievement with stunting status

\begin{tabular}{|c|c|c|c|c|c|c|c|}
\hline \multirow{3}{*}{$\begin{array}{l}\text { Stunting } \\
\text { Status }\end{array}$} & \multicolumn{4}{|c|}{ Academic Achievement } & \multirow[t]{2}{*}{ Total } & \multirow{3}{*}{$\begin{array}{c}\text { OR }(95 \% \\
\text { CI) }\end{array}$} & \multirow{3}{*}{$\begin{array}{c}p \text { - } \\
\text { Value }\end{array}$} \\
\hline & \multicolumn{2}{|c|}{$<$ Average } & \multicolumn{2}{|c|}{$>$ Average } & & & \\
\hline & $\mathrm{n}$ & $\%$ & $\mathrm{n}$ & $\%$ & $\%$ & & \\
\hline Stunting & 15 & 51,72 & 60 & 49,59 & 100 & $1,08(0,446-$ & 0,04 \\
\hline Normal & 14 & 48,28 & 121 & 50,41 & 100 & $2,668)$ & \\
\hline Total & 29 & 100 & 81 & 54 & $150 \quad 100$ & & \\
\hline
\end{tabular}

From the results of the study, it was found that children with stunting and getting less than average academic achievement were $51.72 \%$ and those whose academic achievement was more than the average was $49.59 \%$, while children who were not stunted and got less than average academic achievement. the average was $48.28 \%$ and the average academic achievement was $50.41 \%$. The results of statistical tests show that there is a significant relationship between stunting status and academic achievement. This can be seen from the $\mathrm{p}$-value $=0.04$, while the $\mathrm{OR}$ value obtained is 1.08 (95\% CI: 0.446-2.668), which means that children with stunting status have a 1.08 times likelihood of getting academic achievement less than average. 


\section{DISCUSSION}

Stunting is a condition where there is a failure to thrive in children, caused by chronic malnutrition so that the child becomes short for his age. This malnutrition can occur in the womb and the early stages of a baby's life, however, the condition of stunting is not seen until the baby is 2 years old [9].

The main problem of stunting is caused by malnutrition with the root of the problem being poverty, politics, culture, and the position of women in society. Two things affect stunting, namely heredity or genetics and environmental conditions. It's just that environmental factors have a greater influence on the occurrence of stunting, namely up to $90 \%$ while heredity is only $10 \%$. This is based on WHO research which explains that basically, children should have the same ability in growth, but the role of the environment also affects a child to grow tall. Environmental factors that most likely affect is public awareness to provide adequate and good nutrition in the first 1000 days of a baby's life. If the nutritional intake at that time is sufficient, stunting in children can likely be prevented. In addition to poor nutritional intake, stunting can also be a recurrent infectious disease in children [10].

There have been many pieces of literature that mention the dangers of stunting in children. According to the Logical Frame of The Nutritional Problems from Unicef 2013, this impact can cause short-term or long-term impacts. Examples of the effects of stunting that occur in the short term are stunted brain development, lower IQ, a weak immune system, and high rates of morbidity and disability. While the long-term impact that can occur is that it will lead to short stature in adulthood, loss of productivity and health care, a greater risk of developing diabetes and cancer, a higher risk of causing non-communicable diseases, causing reproductive health problems, and the greater impact will be raises short across generations [1].

Previous research also states that stunted children are also at risk for experiencing difficulties in learning to read when compared to normal children. Stunting can also indicate a disturbance in the organs of the body due to longterm damage, for example, the brain, which can be damaged due to lack of nutrition in children Meanwhile, we all know that the brain is a nerve center that is closely related to children's responses to seeing, hearing, thinking and movement [10].

Research on the effect of stunting on the learning achievement of school children in Kupang and East Sumba, NTT found that with every 1SD increase in the nutritional status of TB / $\mathrm{U}$ children, the children's learning achievement increased by 0.444 , and vice versa. So it is concluded that stunting has a very significant impact on children's learning achievement [11].

Many experts say that the school period is a latent period for children in which what happened and was nurtured in the previous period will continue for the next period [12]. School-age children are children in the 5-12 year age group. At that age, the child's growth begins to enter a slower growth phase. The fastest phase in children is up to 3 years of age and then gradually decreases until the pre-school and school periods. At school age, the growth acceleration curve will form an almost flat curve, then in adolescence, there will be a second growth spurt until it finally stops altogether. The growth and development of children that are included are all changes that occur physically, cognitively, emotionally, and psychosocially [13].

\section{CONCLUSIONS}

There is a significant relationship between the academic achievement of school-age children and stunting status ( $\mathrm{p}$ $=0.04$ ) with an OR value of 1.08 (95\% CI: 0.446-2.668), which means that children with stunting status have a possible risk of 1,08 times to get less than average academic performance. Given the damage that is permanent or permanent and will also affect the quality of life in the future, it is necessary to pay special attention to all lines regarding the management of this stunting. The results of this study which state that there is a relationship between academic achievement and the stunting status of elementary school-age children can be a reference for making policies. For example, by routine screening either by health workers or from the high school student body and conversion to their nutritional status. If there are children who are indicated as stunting at elementary school age, they must be treated by improving nutrition at school or with special attention related to their learning.

\section{REFERENCES}

[1] Trihono, Atmarita, D. H. Tjandarini, A. Irawati , N.H. Utami, T. Tejayanti, et al. Pendek (Stunting) di Indonesia, Masalah Dan Solusinya. Jakarta: Lembaga Penerbit Badan Penelitian dan Pengembangan Kesehatan (Balitbangkes) 2015.

[2] WHO, WHA Global Nutrition Targets 2025: Stunting Policy Brief. World Health Organization, 2014.

[3] UNICEF, Gizi Ibu dan Anak 2012. Available from: https://www.unicef.org/indonesia/id/A6__B_Ringkasan_Kajian_Gizi.pdf. 
[4] RISKESDAS. Laporan Hasil Riset Kesehatan Dasar (RISKESDAS). In: KemenkesRI, editor. Jakarta: Badan Penelitian dan Pengembangan Kesehatan 2018.

[5] A. Yanuarita, Rahasia otak dan kecerdasan anak, Yogyakarta: Teranova Books. 2014.

[6] R. Khanam, H.S. Nghiem, M.M. Rahman. The Impact Of Childhood Malnutrition On Schooling: Evidence From Bangladesh. Journal of Biosocial Science, 2011, 43(4).

[7] S.M. Chang, S.P. Walker, S. Grantham-McGregor, C.A. Powell, Early childhood stunting and later behavior and school achievement, Journal of Child Psychology and Psychiatry, 2002, 43(6):775-83.

[8] B. Kestenbaum, Epidemiology and biostatistics: an introduction to clinical research: Springer, 2019.
[9] TN2PK. Ringkasan-100 Kabupaten/Kota Prioritas Untuk Intervensi Sunting, In: SekretariatWakilPresidenRI, editor. Jakarta: Tim Nasional Percepatan Penanggulangan Kemiskinan, 2017.

[10] Y.A. Widanti, Prevalensi, Faktor Risiko Dan Dampak Stunting Pada Anak Usia Sekolah, 2017.

[11] I. Picauly, S.M. Toy, Analisis determinan dan pengaruh stunting terhadap prestasi belajar anak sekolah di Kupang dan Sumba Timur, NTT. Jurnal Gizi dan Pangan, 2013, 8(1):55-62.

[12] Gunarsa SD. Psikologi Perkembangan Anak Dan Remaja, Jakarta: Gunung Mulia, 2008.

[13] N. Devi, Gizi Anak Sekolah Jakarta: EGC, 2012. 